\title{
57. GEOCHEMISTRY, NORMATIVE MINERALOGY, AND DIFFERENTIATION TRENDS OF BASALT GLASSES FROM DSDP LEG 37
}

\author{
F. Aumento, Dalhousie University, Halifax, Nova Scotia, Canada and \\ D.R.C. Kempe, Department of Mineralogy, British Museum (Natural History), London, England
}

The geochemical investigation of basaltic glasses occurring on the margins of crystalline lavas for which abundant geochemical data are also available may be a key factor in evaluating both the differentiation patterns of the magmas involved and their original compositional variations. In addition, through the ease with which devitrification, and hence alteration, can be detected in these glasses, it is possible to produce analytical data on material for which one may be certain that little or no chemical exchange with seawater has taken place. The latter may not be true for the associated fine-grained rocks, where incipient alteration is not always evident.

Over 190 basalt glasses from Holes 332A, 332B, 332D, 333A and Sites 334 and 335 were analyzed using Cambridge and ARL microprobes at Dalhousie University and the Smithsonian Institution, respectively. Since most the available glasses came from Holes $332 \mathrm{~A}$ and 332B and Site 335, these are dealt with more fully, and some 175 analyses are presented for them in Chapters 2, 3, 4, and 5 (this volume).

The major element concentrations for the glasses from Holes 332A, 332B, and Site 335 are plotted against depth in Figures 1 and 2, where the glass data are superimposed on the compositional fields formed by the associated crystalline whole-rock analyses. Site 335 , which has the simplest geochemistry, serves to evaluate the analytical results rather well. Figure 2 shows two systematic fields of distribution for both $\mathrm{TiO}_{2}$ and $\mathrm{K}_{2} \mathrm{O}$ : in each case the lower values were produced by the ARL probe at the Smithsonian and the higher values by the Cambridge probe at Dalhousie. Other oxide determinations do not show such marked analytical discrepancies, which were traced to the use of different standards by the two laboratories. In addition to these analytical artifacts, a systematic compositional shift between glasses and crystalline rocks is also apparent. The glasses are always relatively enriched in $\mathrm{SiO}_{2}, \mathrm{TiO}_{2}, \mathrm{FeO}^{\text {TOT }}$, and in some instances in $\mathrm{Al}_{2} \mathrm{O}_{3}$ as well, and depleted in $\mathrm{K}_{2} \mathrm{O} . \mathrm{CaO}$ and $\mathrm{Na}_{2} \mathrm{O}$ (and $\mathrm{MgO}$, which is not plotted) do not show systematic differences, although for site $335 \mathrm{CaO}$ in glasses is lower than in their crystalline counterparts. Lower concentrations of potassium, a lithophile element, in the glass phase, is one of the more surprising finds revealed by these plots.

These compositional shifts could result from: (1) the accumulation, in the crystalline rocks, of distinct mineral phases in a groundmass of composition similar to that of the glasses, or (2) the halmyrolysis of the groundmass of the crystalline rocks, in contrast to the fresh glasses selected for analysis. The relative importance of these two factors is evaluated with the data in hand.

The main mineral phases found in both the glasses and the crystalline rocks include plagioclase, olivine, clinopyroxene, and spinels. Addition of model concentrations of these phases to the glasses, thereby approximating the crystalline whole-rock compositions, will cause the $+\mathrm{Ve}$ or $-\mathrm{Ve}$ shifts shown in Table 1. It will be seen that this multiple-phase addition will explain adequately the lower $\mathrm{SiO}_{2}$ and $\mathrm{TiO}_{2}$ content of the rocks compared to the glasses, and may explain in part the similar concentrations of $\mathrm{Al}_{2} \mathrm{O}_{3}$ and $\mathrm{CaO}$ found in both media, but not the tendency for $\mathrm{Al}_{2} \mathrm{O}_{3}$ to be lower, or $\mathrm{CaO}$ to be higher in the crystalline rocks. More important, these mineralogical additions in no way explain the lower $\mathrm{FeO}$ тот and much higher $\mathrm{K}_{2} \mathrm{O}$ values for the rock; similarly, their addition would disrupt the similar $\mathrm{MgO}$ and $\mathrm{Na}_{2} \mathrm{O}$ concentrations found in both the crystalline and glassy media. Obviously, therefore, adding modal amounts of the visible mineral phases to these glasses will not help all the compositional discrepancies to converge; the opposite is true, especially in the case of $\mathrm{K}_{2} \mathrm{O}$ and possible of $\mathrm{Na}_{2} \mathrm{O}, \mathrm{MgO}$, and $\mathrm{FeO}^{\text {TOT }}$

As mentioned previously, halmyrolysis may be the other agent affecting the compositional discrepancies. Table 1 also shows the direction of chemical variations one might expect the glass compositions to take given exposure to seawater (after Hart, 1970, Aumento et al., in press). The effects of halmyrolysis are not completely understood, and on occasion opposing trends have been reported. Halmyrolysis should enhance the mineral addition effects in the cases of $\mathrm{SiO}_{2}$ and $\mathrm{TiO}_{2}$, and assist the otherwise nonexistent $\mathrm{Al}_{2} \mathrm{O}_{3}$ and $\mathrm{CaO}$ trends. At the same time it will enhance the glass/rock divergence by increasing the - $\mathrm{Ve}$ effect of $\mathrm{Na}_{2} \mathrm{O}$ and the $+\mathrm{Ve}$ one of $\mathrm{FeO}^{\text {ror }}$. However, it will oppose the - Ve mineralogical $\mathrm{K}_{2} \mathrm{O}$ effect, thereby providing a possible explanation for the lower $\mathrm{K}_{2} \mathrm{O}$ concentrations found in the fresh glass relative to the crystalline whole rock analyses.

Halmyrolysis, therefore, has affected the crystalline rocks to a considerable extent. We cannot say how much interaction with seawater has altered all the original oxide concentrations since some of the effects have the same trend as those of the mineral additions; other halmyrolysis effects, notably those of $\mathrm{FeO}^{\text {TOT }}$ and $\mathrm{Na}_{2} \mathrm{O}$, seem to have trends opposed to those 


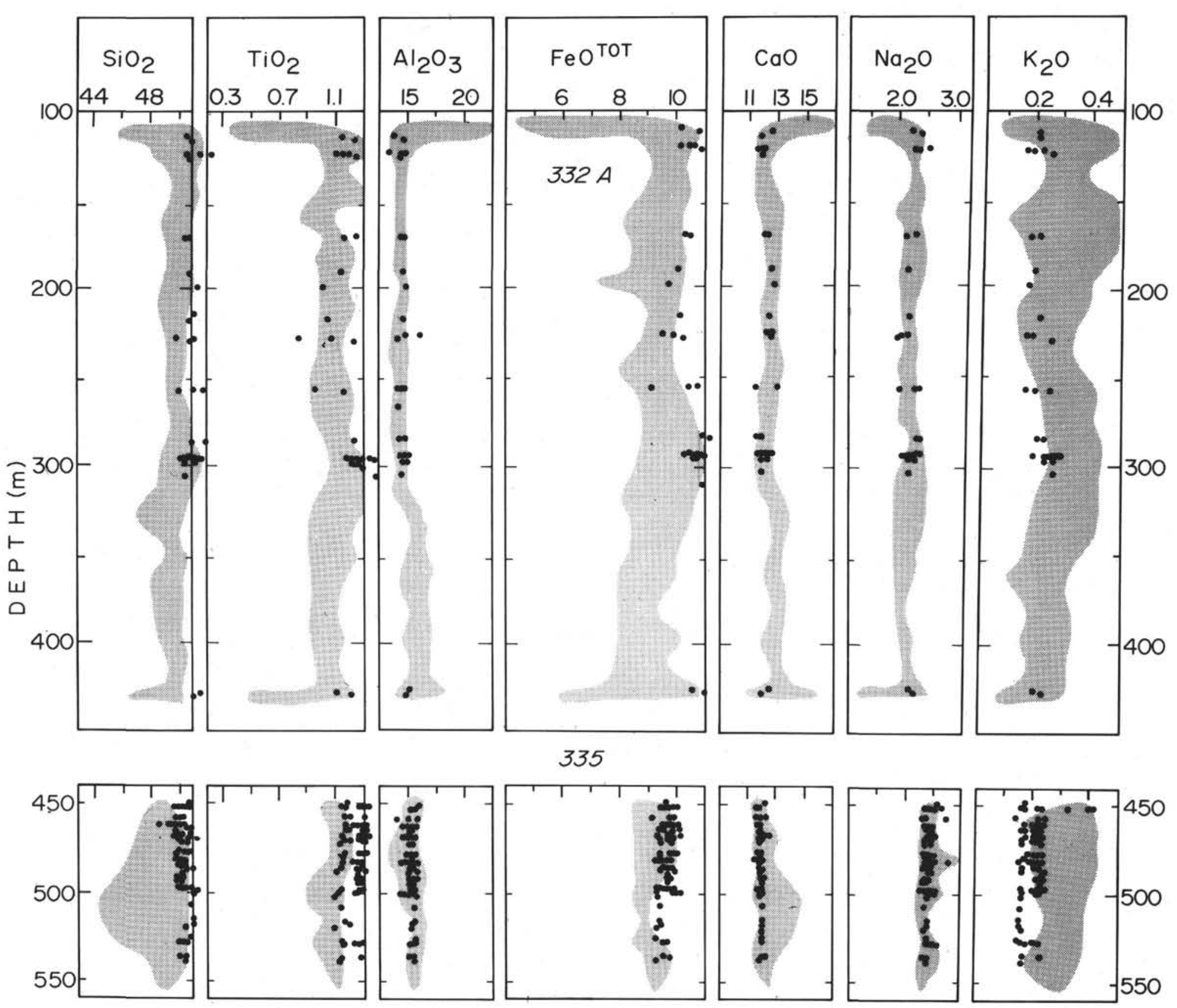

Figure 1. Downhole variations of the major elements in Hole $332 \mathrm{~A}$ and Site 335 glasses superimposed on the whole-rock compositional fields. 


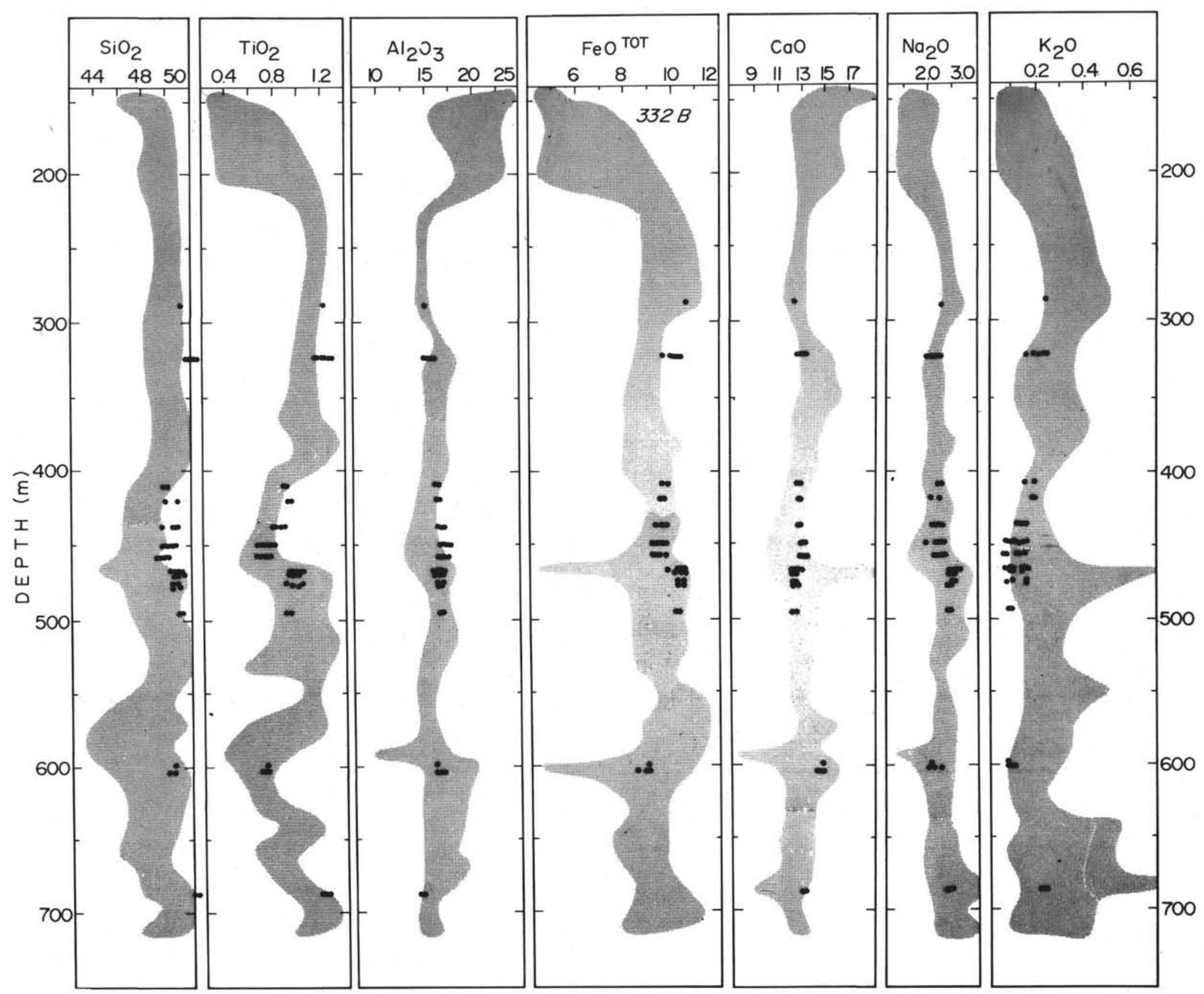


TABLE 1

Summary of Geochemistry, Normative Mineralogy, and Differentiation Trends of Basalt Glasses

\begin{tabular}{|c|c|c|c|c|c|c|c|}
\hline & 1 & 2 & 3 & 4 & 5 & 6 & 7 \\
\hline & $\begin{array}{l}\text { Whole Rock } \\
\text { Composition } \\
\text { Relative to } \\
\text { Glass }\end{array}$ & $\begin{array}{l}\text { Effect } \\
\text { Plag. }\end{array}$ & $\begin{array}{c}\text { Miner } \\
\text { Ol }\end{array}$ & $\begin{array}{l}\text { ditions } \\
\text { CPX }\end{array}$ & $\begin{array}{r}\text { lass } \\
\text { SP }\end{array}$ & $\begin{array}{l}\text { Modal } \\
\text { Mineral } \\
\text { Addition } \\
\text { Effect }\end{array}$ & $\begin{array}{c}\text { Postulated } \\
\text { Halmyrolysis } \\
\text { Effect on } \\
\text { Glass }\end{array}$ \\
\hline $\mathrm{SiO}_{2}$ & - & - & - & $=$ & -- & - & - \\
\hline $\mathrm{TiO}_{2}$ & - & -- & -- & - & -- & -- & - \\
\hline $\mathrm{A}_{1}{ }_{2} \mathrm{O}_{3}$ & -or= & ++ & -- & -- & + & $=$ & - \\
\hline FeOTOT & - & -- & + & + & + & tor $=$ & + \\
\hline $\mathrm{CaO}$ & tor $=$ & + & -- & + & -- & $=$ & + \\
\hline $\mathrm{MgO}$ & $=$ & - & ++ & + & ++ & + & $=$ \\
\hline $\mathrm{Na}_{2} \mathrm{O}$ & $=$ & - & -- & -- & -- & -- & - \\
\hline $\mathrm{K}_{2} \mathrm{O}$ & + & - & -- & -- & -- & -- & + \\
\hline
\end{tabular}

Note: Column 1 gives the relative compositional differences between the whole rock analyses and the associated fresh glasses; columns 2 to 5 give the shifts expected from original glass compositions through the addition of the minerals plagioclase, olivine, clinopyroxene, and spinel; column 6 attempts to show the total overall changes expected in the glass analyses with the addition of modal concentrations of these minerals, and column 7 shows possible halmyrolysis effects on original glass compositions.

Aumento et al. (in press) reported for other oceanic rocks. The latter is not surprising, however, since, for example, the loss of $\mathrm{Na}_{2} \mathrm{O}$ to seawater detected by Aumento et al. (in press) was thought to be remarkable, and the reversal of this trend, reported here, is more acceptable. What is clear, however, is that examination of these fresh glasses offers us the only opportunity of measuring original compositions free from the effects of halmyrolysis. We should use the glass data and apply corrections to the whole rock oxide values measured, thereby reproducing their original, prehalmyrolysis compositions.

The Leg 37 shipboard report noted the existence of a number of repetitive differentiation cycles down the deeper holes. The relative scarcity of fresh glass does not permit us to carry out such detailed studies, but some differentiation trends are still evident.

All but 3 of the 33 Hole $332 \mathrm{~A}$ and the 4 Hole 332D glasses (normalized to $\mathrm{Fe}_{2} \mathrm{O}_{3}=1.50 \%, c c$-free) are quartz tholeiites (PL-tholeiites in the classification of Shido et al., 1971), whereas the 51 of Hole 332B, apart from the 7 of the upper section down to Core 8, are olivine tholeiites (OL-tholeiites) (Figure 3 ). If the true levels of the basalt horizons are equated so that the sediment-basalt contact is 44 meters deeper for Hole 332B than for Hole 332A, it appears that 332A and 332D basalts are equivalent to those of the upper part of 332B and are structurally higher than basalts in the lower part of 332B; thus, the olivine tholeiites below give way to quartz tholeiites higher up. Variations in the positions of the 332B glasses, within the normative olivine tholeiite field, reflect minor changes in chemistry. Glasses from Holes 333A (9) and Site 334 (4) are quartz tholeiites. All but 2 of the 94 glasses from Site 335 are olivine tholeiites. The surprising presence of so many quartz tholeiites among the glasses in the higher levels of the drill holes provides further support for the contention of Kempe (1975) that many drilled basalts, including basalt glasses, which in the past have been recovered only from the upper reaches of the oceanic crust, are quartz normative.

Plots of the $\mathrm{Ab} /(\mathrm{Ab}+\mathrm{An})$ ratios against the $\mathrm{Mg}$ $\left(\mathrm{Mg}+\mathrm{Fe}^{*}+\mathrm{Mn}\right)$ ratios (Figure 4) show the basalt glasses from all holes to be fairly "primitive," forming a trend at Site 332 parallel to the general fractionation trend for tholeiites, with Hole $332 \mathrm{~A}$ basalts being the most differentiated. No differentiation is apparent at Site 335, whereas the cores from Sites 333 and 334- the basalt of the latter closely resembling that from Site 257, Leg 26-(Kempe, 1974) are too short to be plotted.

If the $\mathrm{Mg}$ and $\mathrm{Ab}$ enrichment trends and the $\mathrm{TiO}_{2}$ (wt $\%$ ) content are plotted against normalized normative $o l$ content (positive) or $Q$ content (negative), similar trends are apparent in each case: the three parameters thus reflect the changes in normative mineralogy, and in each other. Even closer correlation is obtained if the $\mathrm{Mg} /\left(\mathrm{Mg}+\mathrm{Fe}^{*}+\mathrm{Mn}\right)$ ratio is plotted against $\mathrm{TiO}_{2}$ for, for example, Site 332. Between the different sites, however, there are considerable differences (Figure 5). Holes $332 \mathrm{~A}$ and 332B show distinct trends towards $\mathrm{Fe} / \mathrm{Mg}, \mathrm{Ab} / \mathrm{An}$, and $\mathrm{TiO}_{2}$ enrichment with increase in normative quartz. Hole 333A shows a slight trend; Site 334 glasses form a group; whereas Site 335 , with a similar range to Site 332 in normative olivine and quartz, shows almost constant $\mathrm{TiO}_{2}$ and, as already stated, little or no $\mathrm{Fe} / \mathrm{Mg}$ and $\mathrm{Ab} / \mathrm{An}$ differentiation. $01=\mathrm{Q}$ variation is thus clearly possible in basalt glasses without $\mathrm{Fe}+\mathrm{Ti} \rightleftharpoons \mathrm{Mg}+\mathrm{Ca}$ fractionation, and the $\mathrm{TiO}_{2}$ content appears to be related to fractionation and not to indicate distinct magma types, as might appear to be the case from the rock analyses. At Site $335, \mathrm{TiO}_{2}$ content is notably higher than in all but a few of the Hole $332 \mathrm{~A}$ glasses.

Finally, when the $\mathrm{FeO}^{*}$ and $\mathrm{CaO}$ variations with depth for Holes 332A and 332B are superimposed such that their respective depths below sediment are 


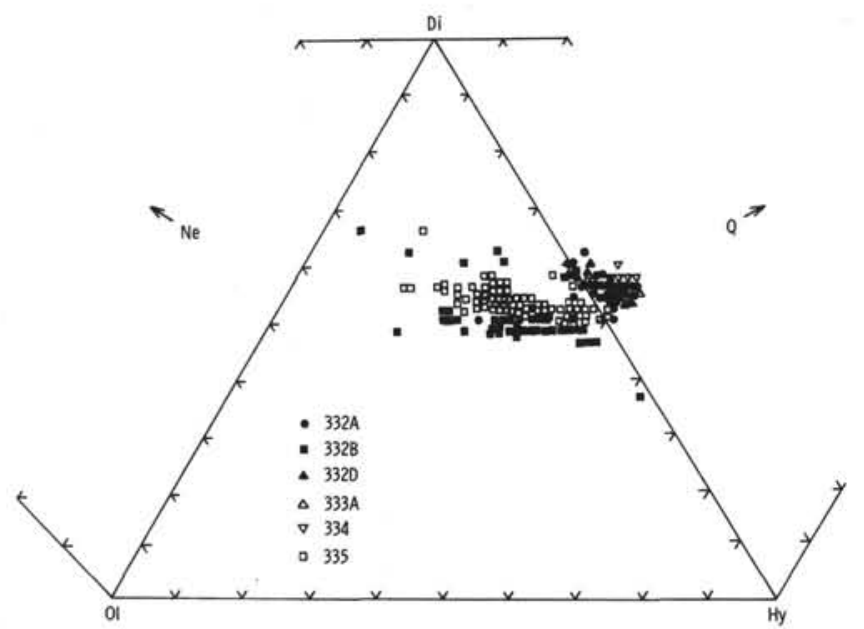

Figure 3. Normative compositions of the Leg 37 basalt glasses, normalized on a cc-free, $\mathrm{Fe}_{2} \mathrm{O}_{3}=1.50 \%$ basis, plotted in the Yoder and Tilley (1962) projection.

equated, there result two smooth continuous oscillatory curves of $\mathrm{FeO}^{*}$ varying antipodally to $\mathrm{CaO}$, with an overall enrichment in $\mathrm{FeO}^{*}$ and depletion in $\mathrm{CaO}$ upwards from Hole 332 B to Hole 332A. Similar undulating curves result if the rock analyses are plotted in the same way. These trends are taken to indicate minor fractionation within each "flow," or each pillow, and an overall $\mathrm{Fe}$ and $\mathrm{Ab}$ enrichment in the total effusion of magma. No major differentiation "jump" is apparent to indicate further effusions, as has been suggested for Site 319, Leg 34 (Kempe, 1975, 1976). In the case of Site 335 glass analyses, no systematic variation with depth and little variation overall (Figure 4), occurs.

In summary, therefore, the Leg 37 basalt glasses are remarkable for their freshness, their unexpectedly wide variation in chemical composition, and, at Site 332, their degree of differentiation, reflected in their normative mineralogy, $\mathrm{Fe} / \mathrm{Mg}$ and $\mathrm{Ab} / \mathrm{An}$ fractionation, and $\mathrm{TiO}_{2}$ and $\mathrm{Al}_{2} \mathrm{O}_{3}$ content.

\section{ACKNOWLEDGMENTS}

Thanks are due to Mr. C.J. Elliott and Dr. G. Johnson for their considerable help with the computing, and to Dr. M. Zerbi and R.M. MacKay for assisting with the electron microprobe. Data on Smithsonian glass analyses provided by W. Melson.

\section{REFERENCES}

Aumento, F., Mitchell, W.S., and Fratta, M., in press. Interaction between sea water and oceanic layer two as a

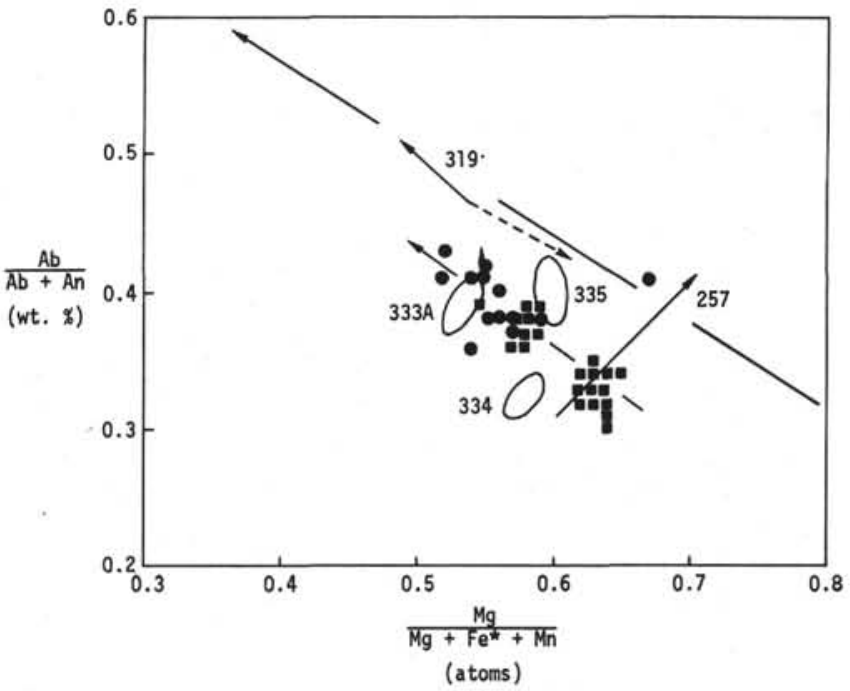

Figure 4. Fractionation diagram $(A b /[A b+A n]$ versus $M g /$ $\left.\left[\mathrm{Mg}+\mathrm{Fe}^{*}+\mathrm{Mn}\right]\right)$ for the Leg 37 glasses. The long broken arrow indicates the generalized fractionation trend for tholeiitic rocks. Hole $332 \mathrm{~A}$ glasses are shown as solid circles; $332 B$ as solid squares; and $332 D$ as solid triangles. For Sites 333, 334, and 335 the fields are shown as enclosed areas. Also shown are the basalt fractionation trends for the long cores from Site 257, Leg 26 (Kempe, 1974) and Site 319, Leg 34. The dashed line (Site 319) indicates large-scale differentiation, possibly between magmatic effusions (Kempe, 1976). In each case, the arrows indicate the upward direction in the drill hole.

function of time and depth. In Water and Magma Genesis symposium volume: Canadian Mineral.

Hart, R., 1970. Chemical exchange between sea water and deep ocean basalts: Earth Planet. Sci. Lett., v. 9, p. 269279.

Kempe, D.R.C., 1974. The petrology of the basalts, Leg 26. In Davies, T.A., Luyendyk, B.P., et al., Initial Reports of the Deep Sea Drilling Project, Volume 26: Washington (U.S. Government Printing Office), p. 465. , 1976. Petrological studies on DSDP Leg 34 basalts: Nazca plate, eastern Pacific Ocean. In Hart, S.R., Yeats, R.S., et al., Initial Reports of the Deep Sea Drilling Project, Volume 34: Washington (U.S. Government Printing Office), p.

Shido, F., Miyashiro, A., and Ewing, M., 1971. Crystallization of abyssal tholeiites: Contrib. Mineral. Petrol., v. 31, p. 251.

Yoder, H.S., Jr., and Tilley, C.E., 1962. Origin of basalt magmas: an experimental study of natural and synthetic rock systems: J. Petrol., v. 3, p. 342. 


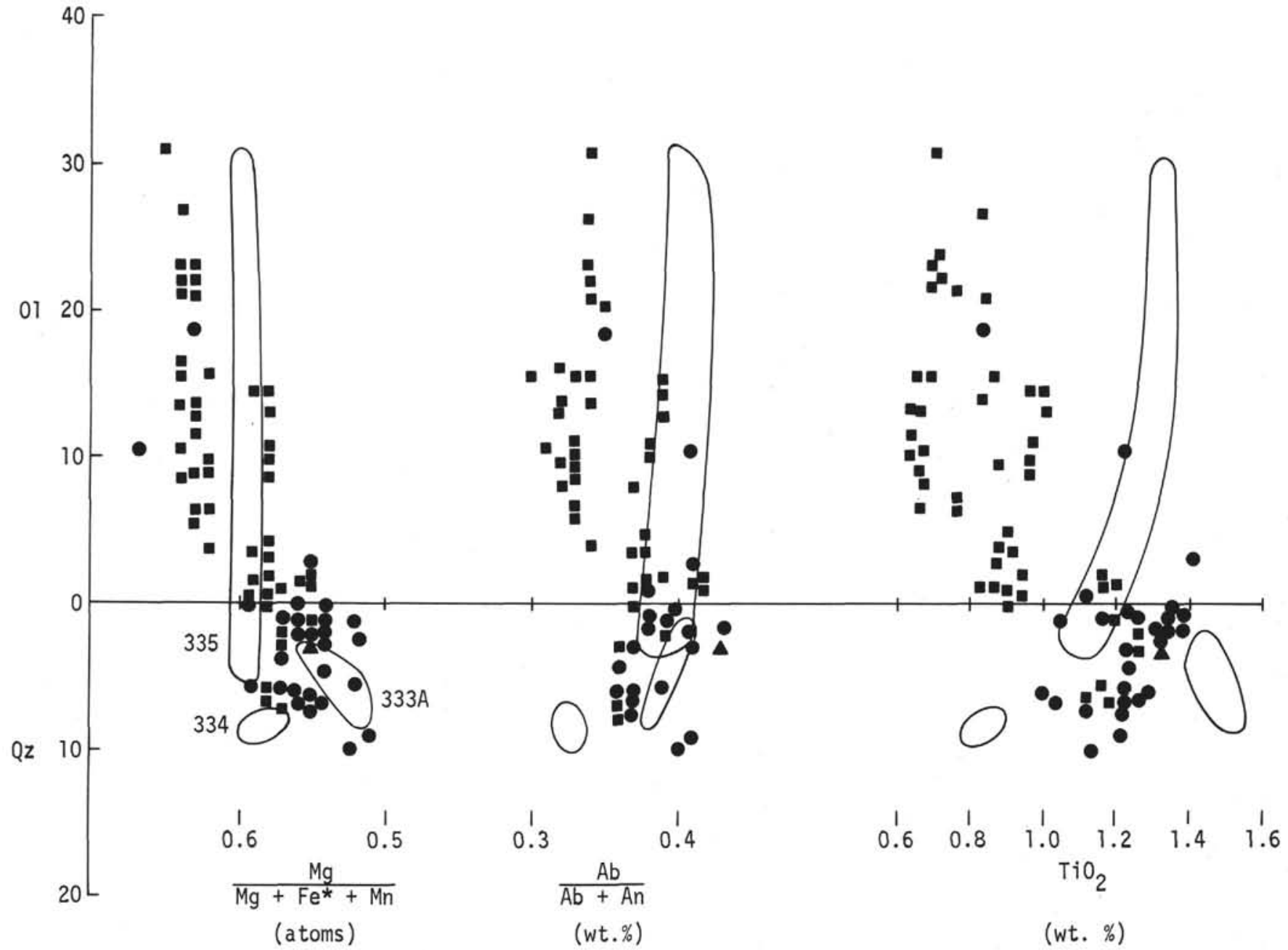

Figure 5. Fractionation trends $\mathrm{Ab} /[\mathrm{Ib}+\mathrm{An}]$ and $\mathrm{Mg} /\left[\mathrm{Mg}+\mathrm{Fe}^{*}+\mathrm{Mn}\right]$, and $\mathrm{TiO}_{2}$ content, for the Leg 37 basalt glasses plotted against (normalized) normative ol or $Q$ content. Similar distributions result if any two of the three parameters forming the abscissa are plotted against each other. Symbols and fields as in Figure 4. 